\title{
Fusarium head blight in the Russian Far East: 140 years after description of the 'drunken bread' problem
}

\author{
Tatiana Gagkaeva ${ }^{\text {Corresp., } 1}$, Aleksandra Orina ${ }^{1}$, Olga Gavrilova $^{1}$ \\ ${ }^{1}$ Laboratory of Mycology and Phytopathology, All-Russian Institute of Plant Protection, St. Petersburg, Pushkin, Russian Federation \\ Corresponding Author: Tatiana Gagkaeva \\ Email address: t.gagkaeva@yahoo.com
}

The first appearance of Fusarium head blight (FHB) - and the beginning of scientific research of this disease-occurred the Far East region of Russia at the end of the 19th century. In the summer of 2019, in the Amur region, which comprises $60-70 \%$ of grain production in the Russian Far East, flooding caused a state of emergency. The quality of wheat and barley grains grown under natural conditions of FHB outbreaks, including grain infection, fungal species composition, F. graminearum DNA content and their chemotypes, and the presence of various mycotoxins, was studied. Fusarium infection rates reached extremely high percentages, 51-98\%, the majority of which were $F$. graminearum infections. The amount of $F$. graminearum DNA in wheat grain samples was higher than in the barley grain samples and averaged 6.1 and $2.1 \mathrm{pg} / \mathrm{ng}$, respectively. The content of deoxynivalenol (DON) in the wheat samples reached 13,343 ppb and in barley reached 7,755 ppb. A multilocus genotyping assay was conducted on the partially sequenced fragments of the translation elongation factor EF-1a, ammonium ligase gene, reductase gene, and 3-0-acetyltransferase gene in 29 Fusarium graminearum sensu lato ( $\mathrm{s}$. lat. ) strains from the grain harvested in the Amur region. All strains from the Far East region were characterized as F. graminearum sensu stricto; $70 \%$ were the $15-A c D O N$ chemotype, while the other strains were the 3-AcDON chemotype. According to the results, after 140 years of study of FHB, we are still not very successful in controlling this disease if conditions are favorable for pathogen development. Even at present, some of the grain harvested must be destroyed, as high contamination of mycotoxins renders it unusable. 


\section{Fusarium head blight in the Russian Far East: 140 years after description of}

\section{2 the 'drunken bread' problem}

3

4 5

6

8

9 Corresponding Author:

10 Tatiana Yu. Gagkaeva

\section{Abstract} reached $7,755 \mathrm{ppb}$.

Tatiana Yu. Gagkaeva, Aleksandra S. Orina, Olga P. Gavrilova

Laboratory of Mycology and Phytopathology, All-Russian Institute of Plant Protection, St.

Petersburg, Pushkin 196608, Russia

Podbelskogo shosse, 3, St. Petersburg, Pushkin 196608, Russia

Email address: t.gagkaeva@yahoo.com

The first appearance of Fusarium head blight (FHB) - and the beginning of scientific research of this disease - occurred the Far East region of Russia at the end of the 19th century.

In the summer of 2019 , in the Amur region, which comprises $60-70 \%$ of grain production in the Russian Far East, flooding caused a state of emergency. The quality of wheat and barley grains grown under natural conditions of FHB outbreaks, including grain infection, fungal species composition, $F$. graminearum DNA content and their chemotypes, and the presence of various mycotoxins, was studied.

Fusarium infection rates reached extremely high percentages, 51-98\%, the majority of which were $F$. graminearum infections. The amount of $F$. graminearum DNA in wheat grain samples was higher than in the barley grain samples and averaged 6.1 and $2.1 \mathrm{pg} / \mathrm{ng}$, respectively. The content of deoxynivalenol (DON) in the wheat samples reached 13,343 ppb and in barley 
A multilocus genotyping assay was conducted on the partially sequenced fragments of the translation elongation factor EF-1a, ammonium ligase gene, reductase gene, and 3-Oacetyltransferase gene in 29 Fusarium graminearum sensu lato (s. lat.) strains from the grain harvested in the Amur region. All strains from the Far East region were characterized as $F$. graminearum sensu stricto; $70 \%$ were the $15-\mathrm{AcDON}$ chemotype, while the other strains were the 3-AcDON chemotype.

According to the results, after 140 years of study of FHB, we are still not very successful in controlling this disease if conditions are favorable for pathogen development. Even at present, some of the grain harvested must be destroyed, as high contamination of mycotoxins renders it 37 unusable.

Keywords: chemotype; deoxynivalenol; disease; DNA; epidemic; Fusarium graminearum; grain; multilocus genotyping; mycotoxins; Russian Far East.

44 The first description of Fusarium head blight (FHB) within the territory of Russia was in the Far East in 1882 (Palchevsky, 1891; Voronin, 1890). This region is typically a monsoon climate with very damp and warm summers due to the influences of the Sea of Japan and the Pacific Ocean. The scientific investigation of this disease began at the end of the 19th century, but long before this, Chinese peasants and later Russian settlers related the poisoning of people and animals with pinkish grains and heads in the fields.

Between 1882 and 1914, epidemics of this disease in the Far East occurred almost every year

51 (Naumov, 1916). Consumption of affected grain and straw caused numerous cases of food 
52 poisoning of people and farm animals. The initial signs and symptoms of the disease resemble

53 those that can develop after drinking too much alcohol (including dizziness and headache,

54 trembling hands, confusion, and vomiting) and thus were named 'drunken bread'. The extensive

55 research undertaken by Russian mycologists revealed that Fusarium roseum Link (F.

56 graminearum Schwabe) with teleomorph stage Gibberella saubinetii Sacc. (G. zeae [Schwein.]

57 Petch) was the principal cause of the disease (Jaczewski, 1904; Naumov, 1916; Voronin, 1890).

58 N.A. Palchevsky (1891), who lived in this territory and was one of the first to report the

59 disease of grain crops, studied its etiology and deposited diseased grain head specimens in

60 herbaria (kept in the Herbarium LEP of our laboratory, the first specimens are dated 1912).

61 Thanks to this inquisitive individual, drawings of typical symptoms of the disease and pathogens

62 were published (Fig. 1).

63 FHB was a persistent problem in the Far East during the 20th century (Abramov, 1938;

64 Naumov, 1916) and continues to be today. High severities of FHB are reported nearly every year

65 in the region. Mycological analyses of seed samples from 1998-2002 have shown a high level of

66 FHB-infected wheat and barley seed (23-32\%). The most frequently isolated pathogen was $F$.

67 graminearum (Gagkaeva et al., 2002; Ivaschenko et al., 2000).

68 Potential toxic effects of mycotoxins associated with FHB, particularly trichothecenes, which

69 are secondary metabolites produced by $F$. graminearum, can result in numerous health problems

70 after consumption of infected grain, flour, and processed products. Fusarium outbreaks are a

71 concern because of loss of grain yield and quality and mycotoxin contamination.

72 The development of multilocus sequence typing (MLST) has facilitated the identification of

73 species and chemotypes of the $F$. graminearum species $(F g)$ group (Ward et al., 2008). Among

74 them, the ubiquitous $F$. graminearum sensu lato (s. lat.) includes at least 16 phylogenetic species 
75 (Aoki et al., 2012; O'Donnell et al., 2000, 2004, 2008) united into the Fg group. Based on MLST

76 assays, several species of the $F g$ group, including $F$. graminearum sensu stricto (s. str.), $F$.

77 ussurianum T. Aoki, Gagkaeva, Yli-Mattila, Kistler \& O'Donnell, and F. vorosii B. Tóth, Varga,

78 Starkey, O'Donnell, H. Suga \& T. Aoki, were identified in the grain grown in the Russian Far

79 East (Yli-Mattilla et al., 2009). A biogeographic hypothesis suggests that $F$. vorosii, F.

80 ussurianum, and F. asiaticum O'Donnell, T. Aoki, Kistler \& Geiser may be endemic Asian

81 species within the Fg group (O'Donnell et al., 2004).

82 All species within the $F g$ group are capable of producing type B trichothecenes, but the

83 activity of their formation is largely different. Three types of chemotypes have been identified

84 among the strains: deoxynivalenol (DON) and 3-acetyldeoxynivalenol (3-AcDON),

85 deoxynivalenol and 15-acetyldeoxynivalenol (15-AcDON), and nivalenol and 4-acetyl-nivalenol

86 (NIV) (Moss, Thrane, 2004; Ward et al., 2002).

87 High humidity and heavy rainfall stimulate the development of $F$. graminearum $\mathrm{s}$. lat. in grain

88 and, as a result, increase its contamination by DON (Aldred, Magan, 2004; Ramirez et al., 2006).

89 The Russian Far East is often exposed to weather disasters, such as floods, which can lead to

90 negative consequences insurmountable by human efforts and technologies resulting in significant

91 agricultural damage. In the summer of 2019, in the Amur region, which accounts for $60-70 \%$ of

92 grain production in the Russian Far East, flooding after substantial rainfall has wreaks havoc

93 with extensive damaged crops. In this region, an emergency regime was established on July 25 ,

942019 , and 'about 250,000 ha was flooded, which amounted to about $20 \%$ of the total cultivated

95 area in the region' (TASS, 2019). As a result, the yield of cereals was only partially saved and

96 harvested. 
97 Despite the long history of the problem in the Far East, there is still no objective information

98

on infection and mycotoxin contamination of harvested grain. Epidemics of FHB in the region fuelled our interest in investigating this disease using available modern methods of research.

Broad geographic surveys of Fusarium species on cereal crops are important to establish if any present shifts in populations occur in response to environmental change. We expected the diversity of Fusarium species belonging to the $F g$ group in this territory to be high, since the conditions were very favorable for fungi and led to the disease epidemic. In addition, we assumed that $F$. asiaticum may appear in the complex of pathogens, since in the neighbouring countries of China and Japan this species is detected on cereals with a high frequency (Gale et al., 2002; Láday et al., 2004; Qu et al., 2007; Suga et al., 2008). In China, where the problem of FHB is also acute, two species of the $F g$ group have been identified: $F$. graminearum s. str. and F. asiaticum (Qu et al., 2007). In the north of China, closest to the Amur Region, mostly $F$. graminearum was dominant, and all of the 15-AcDON chemotypes (Shen et al., 2012). But $F$. asiaticum was the predominant species in the Yangtze River Basin, and chemotypes of strains were either 3-AcDON or NIV, with 3-AcDON being predominant.

This study aimed was to investigate (1) the natural Fusarium species occurrence and mycotoxin contamination of grain from the Amur region in the Far East in the most favorable conditions for pathogens and (2) provide the multilocus analysis of isolated strains of $F$. graminearum sensu lato to species and trichothecene genotype diversity.

\section{Materials \& Methods}

\section{Grain samples and climatic conditions of growth}


119 In mid-August 2019, grain harvest samples were collected in various flood-rescued fields located

120 in the Amur Region, the Russian Far East. These samples were spring wheat (nine samples of the

121 most common Aryuna variety) and barley (four samples of the most common Acha variety).

122 Collecting the representative sample from harvesting at these locations was approved by the

123 Russian Science Foundation (project number: 19-76-30005).

124 The weather in the summer period of 2019 was characterized by disastrous excessive 125 moisture: the total rainfall in July and August was 2.2 and 1.7 times greater, respectively, than 126 the average means of long-term observations (according to https://rp5.ru/). In addition, the 127 number of days with precipitation in these months was 50\% and 39\% more, respectively, than 128 the average means of the climatic norm (Table 1).

129 Mycological analysis of grain

130 Microscopic examination was conducted to reveal the presence of infected grains and perithecia 131 on seed surfaces, and photographs were taken under Olympus BX53 and Olympus SZX16 132 microscopes.

133 One hundred seeds per sample were chosen at random and surface disinfected by soaking in a $1345 \%$ sodium hypochlorite solution for $1-2 \mathrm{~min}$. Then the grains were washed with sterile water 135 and put into Petri dishes on potato sucrose agar medium (PSA) containing $1 \mathrm{~mL} / \mathrm{L}$ of an 136 antibiotics solution (HyClone TM, Austria). Moreover, a commonly used detergent Triton X-100 137 (Panreac, Spain) which reduces the linear fungal growth $(0.4 \mu \mathrm{L} / \mathrm{L})$ was added. After 7-14 days 138 of incubation in the dark at $24^{\circ} \mathrm{C}$, identification and demarcation of taxa were carried out 139 (Gerlach, Nirenberg, 1982; Leslie, Summerell, 2006). The grain infection by the specific taxon 140 of fungi was calculated as the ratio of the number of grains from which these fungi were isolated 141 to the total number of analyzed grains and expressed as the incidence percentage. 


\section{DNA extraction and quantification}

143 The grain samples (20 g) were homogenized separately using sterilized grinding chambers of

144 a batch mill Tube Mill Control (IKA, Königswinter, Germany). The grain flour was stored at -20 $145{ }^{\circ} \mathrm{C}$.

146 The total DNA from $200 \mathrm{mg}$ of grain flour was isolated using the Genomic DNA Purification

147 Kit (Thermo Fisher Scientific, Vilnius, Lithuania) according to the manufacturer's protocol and 148 as previously described in Gagkaeva et al. (2019). Using the same kit, DNA was also isolated 149 from the mycelium of Fusarium spp. strains cultivated on PSA. DNA concentrations from the 150 grain samples and fungal strains were determined using a Qubit 2.0 Fluorometer with a Quant-iT 151 dsDNA HS Assay Kit (Thermo Fisher Scientific, Waltham, MA, USA). Before the start of 152 quantitative PCR (qPCR), the concentrations of all DNA samples were normalized to 23-67 $153 \mathrm{ng} / \mu \mathrm{L}$.

154 In every total DNA sample extracted from grain flour, the DNA content of the $F$.

155 156 157 158

graminearum and $F$. avenaceum was evaluated by qPCR with TaqMan probes (Yli-Mattila et al., 2008). The reaction was carried out in a $20-\mu \mathrm{L}$-volume mixture with $10 \mu \mathrm{L}$ of a $2 \times$ TaqM master mix (AlkorBio, St. Petersburg, Russia), $300 \mathrm{nM}$ of each primer, $100 \mathrm{nM}$ of a fluorescent sample (Evrogen, Moscow, Russia), and $2 \mu \mathrm{L}$ of the corresponding DNA solution.

Additionally, the DNA content of 3-AcDON and 15-AcDON chemotypes of $F$. graminearum was determined using qPCR with SYBR Green (Nielsen et al., 2012). All qPCR assays were run using the CFX 96 Real-Time System thermocycler (Bio-Rad, Hercules, CA, USA). All samples were analyzed at least twice.

Mycotoxin determination by HPLC-MS/MS 
The HPLC-MS/MS multi-mycotoxin method was used to detect different fungal secondary

165

166

167

168

169

170

171

172

173

174

175

176

177

178

179

180

181

182

183

184

185

186

metabolites. In the grain samples, 3-AcDON, 15-AcDON, alternariol (AOH), alternariol

monomethyl ether (AME), beauvericin (BEA), DON, deoxynivalenol-3-glucoside (DON-3gl), diacetoxyscirpenol (DAS), fumonisins B1, B2, and B3, T-2 toxin, HT-2 toxin, T-2 triol, neosolaniol (NEO), fusarenone $\mathrm{X}$, moniliformin (MON), nivalenol (NIV), tentoxin (TEN), tenuazonic acid (TeA), and zearalenone $(\mathrm{ZEN})$ were analyzed.

The analysis of the mycotoxins was carried out following the described procedure (Malachová et al., 2014). Detection and quantification were performed with a QTrap 5500MS/MS system (Applied Biosystems, Foster City, CA, USA) equipped with a TurboV electrospray ionization (ESI) source and a 1290 series UHPLC system (Agilent Technologies, Waldbronn, Germany). Chromatographic separation was performed at $25^{\circ} \mathrm{C}$ on a Gemini ${ }^{\circledR} \mathrm{C} 18$ column, $150 \times 4.6 \mathrm{~mm}$ i.d., with a $5-\mu \mathrm{m}$ particle size, equipped with a C18 SecurityGuard cartridge, $4 \times 3 \mathrm{~mm}$ i.d. (all from Phenomenex, Torrance, CA, USA). Elution was carried out in binary gradient mode. Both mobile phases contained $5 \mathrm{mM}$ of ammonium acetate and were composed of methanol/water/acetic acid ratios of 10:89:1 (v/v/v; eluent A) and 97:2:1 (v/v/v; eluent B), respectively. The recovery of mycotoxins from grain ranged from $79 \%$ to $105 \%$.

\section{Genotyping of Fusarium spp.}

Among isolated fungi that were morphologically assigned to the $F g$ group (nearly 900), 29 monoconidial strains were randomly selected for further molecular analysis. Additionally, four related Fusarium strains with various geographic and substrate origins, the taxonomic status of which requires appraisal, were included in the study (Table 2).

To assess the phylogenetic relationships between all the strains tested, fragments of the translation elongation factor EF-1a $(T E F)$, ammonium ligase gene (URA), reductase gene $(R E D)$, 
187 and 3-O-acetyltransferase gene (Tri101) were used. Their amplification was carried out using 188 specific primers EF1/EF2, URA11/URA16, RED1d/RED2, and TRI1013E/TRI1015B, 189 respectively, according to the authors' protocols and instructions (O'Donnell et al., 2000, 2004, 190 2008).

191 The sequencing was carried out on an ABI Prism 3500 sequencer (Applied Biosystems, 192 Hitachi, Japan) using the BigDye Terminator v3.1 cycle sequencing kit (Applied Biosystems, 193 USA). To address the phylogenetic relationships among taxa maximum likelihood (ML), 194 maximum parsimony (MP) analysis was conducted using the MEGA X 10.2 program (Kumar et 195 al., 2018) as well as Bayesian posterior probability (BP) by MrBayes v. 3.2.1 on the Armadillo 1961.1 platform (Lord et al., 2012). Nodal support was assessed by bootstrap analysis on 1,000 197 replicates. Sequence data were deposited in GenBank.

198 The Fusarium spp. a chemotype (3-AcDON, 15-AcDON, or NIV) was determined using PCR 199 with primers Tri13P1/Tri13P2 according to the authors' protocols and instructions (Wang et al., 200 2008).

201 All tested Fusarium strains are maintained in the collection of the Laboratory of Mycology 202 and Phytopathology at the All-Russian Institute of Plant Protection.

203 Statistical analysis

204 Data were analyzed using Microsoft Office Excel 2010 (Microsoft, Redmond, WA, USA) and 205 Statistica 10.0 (StatSoft, Tulsa, OK, USA). The significance of differences between mean values 206 was estimated by Tukey's test (95\% confidence level).

207

208 Results

209

210

\section{Detection of grain infection with fungi}


211 Visual analysis of grain samples revealed the presence of various deformities, shrunken and 212 with a pink-white coloration of grain heads in the amount of 5-42\% (Fig. 2.). Due to prolonged 213 wet weather, the salmon-orange conidia masses of the fungus and blue-black perithecia can be 214 seen on the infected spikelet and glumes in barley. Most of the perithecia were mature, and when 215 placed in a water drop, the ascospores with three septa appeared from asci.

216 The average germination of wheat grain was $25.1 \%(12-41 \%)$ and of barley grain was $55.3 \%$ 217 (48-62\%). Almost 100\% infection by fungi of all grain samples was noted; often, different fungi 218 were isolated from one grain.

219 Mycology analyses verified that infection by Fusarium spp. was the primary cause of damage 220 in grains, and infection rates reached extremely high percentages (Table 3). Moreover, the 221 proportion of $F$. graminearum s. lat. strains among all isolated Fusarium spp. averaged $83.7 \%$ in 222 the wheat grain and $89.7 \%$ in the barley grain. Fusarium sporotrichioides Sherb. strains were 223 detected in $61 \%$ of samples, but grain infection was low (1-4\%) (the supplemental table). 224 Among the isolated fungi, the occurrence of $F$. avenaceum (Fr.) Sacc., F. anguioides Sherb., $F$. 225 tricinctum (Corda) Sacc., F. poae (Peck) Wollenw., F. cerealis (Cooke) Sacc., F. equiseti 226 (Corda) Sacc., F. incarnatum (Desm.) Sacc., and F. heterosporum Nees et T. Nees as well as 227 four strains belonging to the Fusarium fujikuroi species complex were lower (the supplemental 228 table).

229 Alternaria spp. were the second frequent genera isolated from the grains. Moreover, the 230 infection of wheat grain with Alternaria spp. was almost two times lower $(12.9 \%)$ than that of 231 barley grain (21.5\%). Cladosporium spp., Clonostachys rosea (Link: Fr.) Schroers, Samuels, 232 Seifert \& W. Gams, Cochliobolus spp., Epicoccum nigrum Link, and other fungi were also 233 identified in the grain mycobiota (the supplemental table). 


\section{Quantification of Fusarium biomass}

235 The amount of $F$. graminearum DNA in grain flour was very high, averaging $4.9 \mathrm{pg} / \mathrm{ng}$

236 (Table 3). In analyzed samples of wheat grain, the amount of $F$. graminearum DNA was higher

237 than in the barley grain samples $(\mathrm{p}=0.032)$. The amount of 3-AcDON $F$. graminearum DNA

238 was on average 1.3-1.1 times higher than the content of 15-AcDON genotype DNA. $F$.

239 avenaceum DNA was detected in all grain samples in an amount that was on average 160 times

240 less than that of $F$. graminearum DNA.

241 Detection of mycotoxins

242 DON was found in all samples. The content of DON reached 13,343 ppb in wheat samples

243 and 7,755 ppb in barley samples. In all analyzed samples, the content of DON exceeded the

244 maximum permissible limits (MPLs) in grain for food (700 ppb for wheat grain, 1,000 ppb for

245 barley grain) and fodder (1,000 ppb for cereal grain), by up to 13 times (TR TS 015/2011; TR TS

246 021/2011). The exception was one barley sample, in which the DON content was lower than the

247 MPL: $911 \mathrm{ppb}$.

248 In addition, other type B trichothecene mycotoxins, 3-AcDON, 15-AcDON, and DON-3gl, 249 were detected in the grain. Of the total content of trichothecenes, the share of DON in wheat 250 grain was $86.5 \%$ and in barley grain was $69.5 \%$.

251 The content of ZEN produced by $F$. graminearum in wheat grain $(92-3,670 \mathrm{ppb})$ was on 252 average 2.1 times higher than in barley grain (111-928 ppb).

253 Low contents of T-2 toxin (5 and $15 \mathrm{ppb})$ and HT-2 toxin (23 and $58 \mathrm{ppb}$ ) produced by $F$. 254 sporotrichioides were detected in two barley grain samples.

255 The MON produced by F. avenaceum was detected in all samples in amounts up to $218 \mathrm{ppb}$ 256 without differences between crops. The mycotoxin BEA was detected in only two wheat samples 
257 in amounts up to $13 \mathrm{ppb}$. The fumonisins NEO, DAS, and fusarenone $\mathrm{X}$ produced by Fusarium

258 fungi were not detected in the analyzed grain samples.

259 The mycotoxin $\mathrm{AOH}$ produced by Alternaria fungi was detected in all grain samples in small 260 amounts (8-49 ppb). Moreover, the content of this mycotoxin in barley grain, 11.7 (7.6-17.2), 261 was significantly lower than in wheat grain, $29.0(14.2-49.1)(p=0.032)$. AME was found in all 262 analyzed grain samples except for two wheat samples in trace amounts. TeA was detected in all 263 barley grains with a maximal level of $37.4 \mathrm{ppb}$ and in $44 \%$ of wheat samples with a maximal 264 level of $75.0 \mathrm{ppb}$ (the supplemental table). Traces of TEN were found in all samples (max 6.4 $265 \mathrm{ppb})$.

\section{Genotyping of Fusarium spp.}

267 Multilocus analyses of the TEF, URA, RED, and Tri101 sequences were used to determine the 268 genetic relationships among Fusarium strains. The dataset included 34 combined sequences of 269 the analyzed strains as well as the 12 reference sequences of Fusarium spp. belonging to the $\mathrm{Fg}$ 270 group and consisted of a total of 2,941 characters (612 bp from the TEF, $558 \mathrm{bp}$ from URA, 821

271 bp from RED, and $950 \mathrm{bp}$ from Tri101). The sequence of the $F$. pseudograminearum type strain 272 NRRL 28334 was used as the outgroup. The resulting phylogenetic tree based on DNA sequence 273 data of Fusarium species was constructed (Fig. 3). Maximum likelihood and MP bootstrap 274 support values greater than $70 \%$, followed by Bayesian posterior probability scores greater than 2750.95 , are shown at the nodes.

276 The topology of phylogenetic trees constructed by different methods turned out to be similar 277 and demonstrated the phylogenetic relationships between species established earlier (Aoki et al., 278 2012). Twenty-nine analyzed Fusarium strains isolated from Amur grain belonged to the clade 279 with reference strain NRRL 5883 F. graminearum s. str. (Fig. 3). Among the analyzed strains of 
280 281 282 283 284 285 286 287 288 289 290 291 292 293 294 295 296 297 298 299 300 301 302

F. graminearum s. str., nine strains were the $3-A c D O N$ chemotype while 21 strains turned out to be the 15-AcDON chemotype (Table 2).

From four doubtful Fusarium strains, one strain MFG 60604, isolated from wheat grain from the Altai Krai (Western Siberia), was clustered with the reference strain F. vorosii NRRL 45790 with high bootstrap support (ML/MP/BP: 99/99/1.0). Our phylogenetic analysis indicates that strain MFG 60604 is $F$. vorosii and it is determined as a 15-AcDON chemotype.

Three other doubtful strains, MFG 58836, MFG 59052, and MFG 60755, formed the clade with the reference strains $F$. culmorum NRRL 25475 with high bootstrap support (ML/MP: 98/100). All three F. culmorum strains were the 3-AcDON chemotype (Table 2).

\section{Discussion}

Despite the long history of the FHB problem in the Russian Far East, objective data on pathogen composition and content of mycotoxins in naturally infected grain is clearly underpublished. The mycological analyses of grain from this region in 2019 revealed extremely high infection of grain with Fusarium spp.- up to $98 \%$. The predominant cause of FHB was the Fg group, which accounted for $86 \%$ of all isolated Fusarium spp.

Interestingly, the amount of fungal DNA in the wheat grain was on average higher than in the barley grain, while the percentage of infected grains was the same. The revealed differences may be due to the abundance of fungal biomass concentrated on the surface of barley grains (husk, palea, pericarp), while the wheat grain is completely permeated with fungal hyphae. In general, in this situation in 2019 , the infection rates for both wheat and barley were off the scale. In our opinion, the highest DON content detected in this study, in the amount of 13,343 ppb, exceeds the maximum amounts of this mycotoxin in grain previously detected in the Russian territory. During the outbreak of FHB in southern Europe in 1985-1991 the maximal content of DON in 
303 grain reached 10,000 ppb (Kononenko, 2005). Recently, in 2017, a DON amount of 7,920 ppb

304 was detected in wheat grain grown in southern Europe (Kononenko et al., 2020).

305 The content of 3-AcDON in wheat and barley grain, as well as 15-AcDON, was similar and 306 did not exceed $293 \mathrm{ppb}$. In the plant, DON can be present as a metabolite, DON-3gl, which is 307 represents up to $46 \%$ of the total amount of DON in infected wheat and maize varieties 308 (Berthiller et al. 2009). It has been shown that DON-3gl can be converted back to DON in 309 mammals (Dall'Erta et al., 2013; Tucker et al., 2019). Therefore, DON-3gl is also frequently

310 referred to as a masked mycotoxin. In our study, the maximum content of DON-3gl reached

$3113,803 \mathrm{ppb}$ and was twice as high, on average, in barley grain than in wheat grain. The amounts of

312 DON-3gl come to $13.5 \%$ and $39.5 \%$ of the total amounts of DON in infected wheat and barley

313 samples, respectively. However, there were no significant differences in the content of the

314 trichothecene mycotoxin average between wheat and barley grains.

315 Using morphology to accurately assess species limits for the $F g$ group is not reliable. Before 316 this study, we hypothesized that in the extremely humid and warmest conditions of 2019, in the 317 area where FHB outbreaks were observed for at least 140 years, several species of the Asian 318 clade of the $F g$ group will be identified. Especially considering that earlier we have already 319 found three species of the $F g$ group in this region: $F$. graminearum s. str., F. ussurianum and $F$. 320 vorosii (Yli-Mattila et al., 2009). Selecting freshly isolated fungi for analysis, we took cultures 321 for a detailed study, which included all the morphological diversity present within the limits 322 possible for the $F g$ group (pigmentation, rate of formation of macroconidia, size, and shape).

323 Multilocus phylogenetic analysis revealed that all strains from the Amur grains belonged to the $324 \quad F$. graminearum s. str. 
Molecular methods make it possible to reveal the intraspecific diversity of $F$. graminearum

326

327

328

329

330

331

332 333

334

335

336

337

338

339

340

341

342

343

344 345 346

and to establish the quantitative presence of two different chemotypes. The $F$. graminearum strains are divided into 3-AcDON and 15-AcDON chemotypes depending on the prevailing acetylated form of DON (Alexander et al., 2011; Foround et al., 2019). Regional differences have been reported regarding the occurrence of chemotypes within the $F g$ group (Foround et al., 2019; Pasquali et al., 2016). In our study, on average, the DNA content of the 3-AcDON and 15 AcDON fungus chemotypes in the grain was similar, but the DNA of the 15-AcDON chemotype in wheat grain was significantly higher (4.6 times) than in barley $(p=0.014)$, whereas the difference in DNA content of the 3-AcDON fungus chemotype in wheat and barley grain was insignificant. It is not known whether the observed differences are related to chemotype-specific plant-host preferences. There may be a difference in pathogenicity between the 3 - and 15-ADON chemotypes to wheat and barley (Foroud et al., 2019; Clear et al., 2013).

According to our results, $30 \%$ of the analyzed $F$. graminearum strains were the 3 -AcDON chemotype, while $70 \%$ of the strains were the $15-\mathrm{AcDON}$ chemotype. Previously, the chemotype analysis of the 105 F. graminearum strains collected in the Russian Far East in 1998-2006 revealed the approximately equal occurrence of $3-\operatorname{AcDON}(48 \%)$ and $15-\operatorname{AcDON}(52 \%)$ chemotypes (Yli-Mattila et al., 2009). An increase in the 15-ADON chemotype has recently been shown in regions of Europe, where the 3-ADON chemotype was previously dominant, although many of the factors affecting their distribution are still unclear (Nielsen et al., 2012; Aamot et al., 2015; Pasquali et al., 2016; Foround et al., 2019). The third chemotype of F. graminearum s. str. producing nivalenol (NIV) has not yet been identified in Russia or China (Shen et al., 2012), although it is known to be found in Europe (Pasquali et al., 2016).

PeerJ reviewing PDF | (2021:05:61017:3:0:NEW 20 Sep 2021) 
In our analysis, Fusarium sp. strain MFG 60604 was included that was isolated from wheat

348

349

350

351

352

353

354

355

356

357

358

359

360

361

362

363

364 365

366

367

368

369

grain in the Western Siberia region (the Altai Krai); phenotypically, this strain was a dubious

representative of the $F g$ group. In this region, the occurrence of $F$. graminearum was previously not typical, but in recent years, we have been identifying this pathogen in cereal grains

(Gagkaeva et al., 2019). The strain MFG 60604, isolated from wheat grain from West Siberia, was clustered with the reference strain $F$. vorosii NRRL 45790 with high bootstrap support (ML/MP/BP: 98/99/1.0), which allows for accurate establishment of its species affiliation. A single strain (MFG 60604) identified as F. vorosii in this study, is the only third strain of $F$. vorosii found in Russia and the first one identified in the Siberian region. Previously identified strains of F. vorosii from the Russian Far East belonged to the 15-AcDON chemotype (YliMattila et al., 2009) and so did the strain identified in this study. However, among six $F$. vorosii strains originating from Korea, five were the NIV chemotype, while only one was the 15AcDON (Lee et al., 2016). Among F. vorosii, no strains of the 3-AcDON chemotype have been identified, which, probably, were not detected due to the small number of strains of this species analyzed to date. In the limited surveys to date, strains of several species of the $F g$ group were found to represent only a single chemotype (Aoki et al., 2012).

Two strains of F. culmorum of closely related taxon to $F g$ group from the Western Siberia and Ural regions and one from the South European region of Russia were included in the study. The high genetic similarity of analyzed F. culmorum strains collected from remote regions characterized by different climatic conditions (the distance between isolation points is about $2,500 \mathrm{~km}$ ) is consistent with the previously shown information that $F$. culmorum is a single phylogenetic species with little or no differences between lineages, despite the geographic separation of genotypes (Obanor et al., 2010).

Peer] reviewing PDF | (2021:05:61017:3:0:NEW 20 Sep 2021) 
370 The studies analyzing the occurrence of $F$. culmorum chemotypes in different regions, as a

371 rule, show a significant excess of the occurrence of the DON chemotype compared to the NIV

372 chemotype (Laraba et al., 2017; Pasquali et al., 2016; Scherm et al., 2012). Strains of the 15-

373 AcDON chemotype typical for $F$. graminearum were not identified among the strains of $F$.

374 culmorum. A previous analysis of a few strains of $F$. culmorum from the Russian territory has

375 characterized them as the 3-AcDON chemotype (Yli-Mattila et al., 2009).

$376 \quad$ Fusarium spp. continue to pose a threat to farmers, destroying crops or dramatically reducing

377 yields, as well as to animal and human health due to the production of mycotoxins. Even in our

378 time, when we know much more about the nature of Fusarium spp. then 140 years ago, we are

379 still not very successful in controlling the diseases they cause on crops if conditions are favorable

380 for the development of pathogens. Indeed, in the process of our study, it was shown in the mass

381 media that although the grain was harvested with great difficulty, due to the significant

382 contamination of the grain, part of the crop, 240 tons, had to be destroyed by fire.

383

384

385

386

387

388

389

390

391

392

393

\section{Conclusions}

The high prevalence of Fusarium head blight in cereal grains cultivated in the Far East is particularly alarming and strongly indicates the need for increased measures to prevent plant infection and improved food safety interventions. The maximum DON content in wheat grains reached $13,141 \mathrm{ppb}$ in this study. The multilocus sequence revealed that the majority of the strains used in this study belonged to $F$. graminearum s. str.

\section{Acknowledgments}


394 We are grateful to the managers of the Russian Branch of BASF company for their help with the 395 grain sample collection and Nadezhda N. Gogina from the All-Russian Scientific and 396 Technological Institute of Poultry (Moscow region) for carrying out HPLC-MS/MS analysis.

397

398

399

400

401

402

403

404

405

406

407

408

409

410

411

412

413

415

416

417

414 Clear RM, Tucker JR, Gaba D, Patrick SK, Lee SJ, Demeke T, Tittlemier SA, Legge

\section{References}

Aamot HU, Ward TJ, Brodal G, Vrålstad T, Larsen GB, Klemsdal SS, Elameen A, Uhlig S, Hofgaard IS. 2015. Genetic and phenotypic diversity within the Fusarium graminearum species complex in Norway. European Journal of Plant Pathology 142: 501-519 https://doi.org/10.1007/s10658-015-0629-4

Abramov IN. 1938. Diseases of agricultural plants on the Far East. Far Eastern State Regional Publishing House, Khabarovsk. (in Russian)

Aldred D, Magan N. 2004. Prevention strategies for trichothecenes. Toxicology Letters 153:165-171 https://doi.org/10.1016/j.toxlet.2004.04.031

Alexander NJ, McCormick SP, Waalwijk C, van der Lee T, Proctor RH. 2011. The genetic basis for 3-ADON and 15-ADON trichothecene chemotypes in Fusarium graminearum. Fungal Genetics and Biology 48:485-495 https://doi.org/10.1016/j.fgb.2011.01.003

Aoki T, Ward T, Kistler H, O'Donnell K. 2012. Systematics, phylogeny and trichothecene mycotoxin potential of Fusarium head blight cereal pathogens. Mycotoxins 62:91102 https://doi.org/10.2520/myco.62.91 WG, Gräfenhan T. 2013. Deoxynivalenol levels and chemotype frequency in barley cultivars inoculated with two chemotypes of Fusarium graminearum. Canadian Journal of Plant Patholology 35: 37-45 https://doi.org/10.1080/07060661.2012.751622 
419 efficiently hydrolyzed by human colonic microbiota releasing their aglycones. Chemical

420 Toxicology Research 26:305-312. http://dx.doi.org/10.1021/tx300438c

421 Foround NA, Baines D, Gagkaeva TYu, Thakor N, Badea A., Steiner B., Bürstmayr M,

422 Bürstmayr H. 2019. Trichothecenes in cereal grains - an update. Toxins 11:634

423 http://dx.doi.org/10.3390/toxins 11110634

424

Gagkaeva T, Gavrilova O, Orina A, Lebedin Y, Shanin I, Petukhov P, Eremin S. 2019.

425

426

427

428

429

430

431

432

433

434

435

436

437

438

439

Analysis of toxigenic Fusarium species associated with wheat grain from three regions of

Russia: Volga, Ural, and West Siberia. Toxins 11:252 https://doi.org/10.3390/toxins11050252

Gagkaeva TYu, Levitin MM, Zuev E, Terentjeva I. 2002. Evaluation of genetic resources of wheat and barley from Far East of Russia for resistance to Fusarium head blight. Journal of Applied Genetics 43A:229-236

Gale LR, Chen L-F, Hernick CA, Takamura K, Kistler HC. 2002 Population analysis of Fusarium graminearum from wheat fields in Eastern China. Phytopathology 92:1315-1322 https://doi.org/10.1094/PHYTO200292121315

O’Donnell K, Ward TJ, Geiser DM, Kistler HC, Aoki T. 2004. Genealogical concordance between the mating type locus and seven other nuclear genes supports formal recognition of nine phylogenetically distinct species within the Fusarium graminearum clade. Fungal Genetics and Biology 41: 600-623 https://doi.org/10.1016/j.fgb.2004.03.003

Gerlach W, Nirenberg HI. 1982 The genus Fusarium-A Pictorial Atlas. In: Mitteilungen aus der Biologischen Bundesanstalt fur Land- und Forstwirtschaft, Berlin-Dahlem;

Herausgegeben von der Biologischen Bundesanstalt für Land- und Forstwirtschaft, Berlin, 209 
441 fungi on cereals in the Asian part of Russia. Mikologia I Fitopatologia 34:54-68 (In Russian)

and wild useful plants 11:89-92 (In Russian)

445 in genetically engineered crops and feed additives. Applied Microbiology and Biotechnology

446 91:491-504 https://doi.org/10.1007/s00253-011-3401-5

Kononenko GP. 2005. The system of mycotoxicological control of objects of veterinary,

448

449

450

451

452

453

454

455

456

457

458

459

460

461 sanitary and environmental supervision. Theses of the doctoral dissertation, Moscow

Kononenko GP, Burkin AA, Zotova YeV. 2020. Mycotoxicological monitoring Part 3

Feedstuffs from raw grain processing. Veterinary Science Today 3:213-219

https://doi.org/10.29326/2304-196X-2020-3-34-213-219

Kumar S, Stecher G, Li M, Knyaz C, Tamura K. 2018. MEGA X: Molecular

evolutionary genetics analysis across computing platforms. Molecular Biology and Evolution

35:1547-1549 https://doi.org/10.1093/molbev/msy096

Láday M, Juhász. Á, Mulé G, Moretti A, Szécsi A, Logrieco A. 2004. Mitochondrial

DNA diversity and lineage determination of European isolates of Fusarium graminearum

(Gibberella zeae). European Journal Plant Pathology 110:545-550

https://doi.org/10.1023/B:EJPP0000032394391302c

Laraba I, Boureghda H, Abdallah N, Bouaicha O, Obanor F, Moretti A, Geiser DM, Kim H-S, McCormick SP, ProctorRH, KellyAC, Ward TJ, O'Donnell K. 2017. Population genetic structure and mycotoxin potential of the wheat crown rot and head blight pathogen Fusarium 
462 culmorum in Algeria. Fungal Genetics and Biology 103:34-41

463 https://doi.org/10.1016/jfgb201704001

464 Lee T, Paek J-S, Lee K, Lee S, Choi J-H, Ham H, Hong S, Ryu J-G. 2016. Occurrence of 465 toxigenic Fusarium vorosii among small grain cereals in Korea. Plant Pathology Journal 32:407466413 https://doi.org/10.5423/PPJOA0520160123

467 Leslie JF, Summerell BA. 2006. The Fusarium laboratory manual. Blackwell Publishing, 468 Ames https://doi.org/10.1002/9780470278376

469 Lord E, Leclercq M, Boc A, Diallo AB, Makarenkov V. 2012. Armadillo 11: An original 470 workflow platform for designing and conducting phylogenetic analysis and simulations. PLoS 471 ONE 7:e29903 https://doi.org/10.1371/journalpone0029903

472 Malachová A, Sulyok M, Beltrán E, Berthiller F, Krska. R. 2014. Optimization and 473 validation of a quantitative liquid chromatography-tandem mass spectrometric method covering 474295 bacterial and fungal metabolites including all regulated mycotoxins in four model food 475 matrices. Journal of ChromatographyA 1362:145-156

476 https://doi.org/10.1016/jchroma201408037

477 Moss MO, Thrane U. 2004. Fusarium taxonomy with relation to trichothecene formation. 478 Toxicology Letters 153:23-28 https://doi.org/10.1016/jtoxlet200404021

479 Naumov NA. 1916. Drunken bread Observations under some species of genus Fusarium 480 Bureau of Mycology and Phytopathology, Petrograd (In Russian)

481 Nielsen LK, Jensen JD, Rodríguez A, Jørgensen LN, Justesen AF. 2012. TRI12 based 482 quantitative real-time PCR assays reveal the distribution of trichothecene genotypes of $F$ 483 graminearum and F culmorum isolates in Danish small grain cereals. International Journal of 484 Food Microbiology 157:384-392 https://doi.org/10.1016/jijfoodmicro201206010 
phylogeographic structure and reproductive isolation among lineages of Fusarium graminearum,

487 the fungus causing wheat scab. PNAS 97:7905-7910 https://doi.org/10.1073/pnas130193297

O’Donnell K, Ward TJ, Aberra D, Kistler HC, Aoki T, Orwig N, Kimura M, Bjornstad

A, Klemsdal SS. 2008. Multilocus genotyping and molecular phylogenetics resolve a novel head

blight pathogen within the Fusarium graminearum species complex from Ethiopia. Fungal

491

492

493

494

495

496

497

498

499

500

501

502

503

504

505

506

507
Genetics and Biology 45:1514-1522 https://doi.org/10.1016/jfgb200809002

O’Donnell K, Ward TJ, Geiser DM, Kistler HC, Aoki T. 2004. Genealogical concordance between the mating type locus and seven other nuclear genes supports formal recognition of nine phylogenetically distinct species within the Fusarium graminearum clade. Fungal Genetics and Biology 41:600-623 https://doi.org/10.1016/jfgb200403003

Obanor F, Erginbas-Orakci G, Tunali B, Nicol JM, Chakraborty S. 2010. Fusarium

culmorum is a single phylogenetic species based on multilocus sequence analysis. Fungal

Biology 114:753-765 https://doi.org/10.1016/jfunbio201007001

Palchevsky NA. 1891 Diseases of cultivated cereals of the South Ussuri region Public

Benefit Partnership, Saint Petersburg (In Russian)

Pasquali M, Beyer M, Logrieco A, Audenaert K, Balmas V, Ryan Basler R, BoutignyA-

L, Chrpová J, Czembor E, Gagkaeva T, González-Jaén MT, Hofgaard IS, Köycü ND, Hoffmann

L, Lević J, Marin P, Miedaner T, Migheli Q, Moretti A, Müller MEH, Munaut F, Parikka P,

Pallez-Barthel M, Piec J, Scauflaire J, Scherm B, Stanković S, Thrane U, Uhlig S, Vanheule A,

Yli-Mattila T, Vogelgsang S. 2016. A European database of Fusarium graminearum and F

culmorum trichothecene genotypes. Frontiers in Microbiology 7:406

https://doi.org/10.3389/fmicb201600406

Peer] reviewing PDF | (2021:05:61017:3:0:NEW 20 Sep 2021) 
509 YC. 2007. Geographic distribution and genetic diversity of Fusarium graminearum and

510 Fusarium asiaticum on wheat spikes throughout China. Plant Pathology 57:15-24

511 https://doi.org/10.1111/j1365-3059200701711x

513 growth and temporal deoxynivalenol production by two Argentinean strains of Fusarium

514 graminearum on irradiated wheat grain. International Journal of Food Microbiology 106:291-

515296 https://doi.org/10.1016/jijfoodmicro200509004

516 Scherm B, Balmas V, Spanu F, Pani G, Delogu G, Pasquali M, Migheli Q. 2012.

517 Fusarium culmorum: causal agent of foot and root rot and head blight on wheat. Molecular Plant

518 Pathology 14:1-19 https://doi.org/10.1111/mpp12011

519 Shen CM, Hu YC, Sun HY, Li W, Guo JH, Chen HG. 2012. Geographic distribution of

520 trichothecene chemotypes of the Fusarium graminearum species complex in major winter wheat

521 production areas of China. Plant Disease 96:1172-1178 https://doi.org/10.1094/PDIS-11-11-

522 0974-RE

523 Suga H, Karugia GW, Ward T, Gale LR, Tomimura K, Nakajima T, Miyasaka A,

524 Koizumi S, Kageyama K, Hyakumachi M. 2008. Molecular characterization of the Fusarium

525 graminearum species complex in Japan. Phytopathology 98:159-166

526 https://doi.org/10.1094/PHYTO-98-2-0159

527

TASS, 2019. The flood damage in 2019 in the Amur region is estimated at more than 6

528 billion rubles. 16 Sept. 2019. https://tass.ru/ekonomika/6888626 (In Russian)

529 TR TS 015/2011 Technical regulation of the Customs Union 015/2011 "About grain

530 safety" as amended on September 15, 2017 Supplement No 2 Available online: 
531 http://www.eurasiancommission.org/ru/act/texnreg/deptexreg/tr/Documents/TP_zepно.pdf (In 532 Russian) (accessed 7 May 2021)

533 TR TS 021/2011 Technical regulation of the Customs Union 021/2011 " About food 534 safety" as amended on August 8, 2019 Supplement No 3 Available online:

535 http://www.eurasiancommission.org/ru/act/texnreg/deptexreg/tr/Documents/TR\%20TS\%20Pishe 536 vayaProd.pdf(In Russian) (accessed 7 May 2021)

537 Tucker JR, Badea A, Blagden R, Pleskach K, Tittlemier SA, Fernando WGD. 2019.

538 Deoxynivalenol-3-glucoside content is highly associated with deoxynivalenol levels in two-row

539 barley genotypes of importance to Canadian barley breeding programs. Toxins 11:319

540 https://doi.org/10.3390/toxins 11060319

541 Voronin MC. 1890. About drunken bread in the South Ussuri region. Botanical notes

542 3:13-21 (In Russian)

543 Wang J, Li H, Qu B, Zhang J, Huang T, Chen F, Liao Y. 2008. Development of a generic

544 PCR detection of 3-acetyldeoxynivalenol, 15-acetyldeoxynivalenol- and nivalenol-chemotypes

545 of Fusarium graminearum clade. International Journal of Molecular Sciences 9:2495-2504

546 https://doi.org/10.3390/ijms9122495

547 Ward TJ, Bielawski JP, Kistler HC, Sullivan E, O'Donnell K. 2002. Ancestral

548 polymorphism and adaptive evolution in the trichothecene mycotoxin gene cluster of

549 phytopathogenic Fusarium. PNAS 99:9278-9283 https://doi.org/10.1073/pnas142307199

550 Ward TJ, Clear R, Rooney A, O’Donnell K, Gaba D, Patrick S, Starkey DE, Gilbert J,

551 Geiser DM, Nowicki TW. 2008. An adaptive evolutionary shift in Fusarium head blight

552 pathogen populations is driving the rapid spread of more toxigenic Fusarium gramienarum in 
553 North America. Fungal Genetics and Biology 45:473-484

554 https://doi.org/10.1016/j.fgb.2007.10.003

555 Yli-Mattila T, GagkaevaT, Ward TJ, Aoki T, Kistler HC, O’Donnell K. 2009. A novel

556 Asian clade within the Fusarium graminearum species complex includes a newly discovered

557 cereal head blight pathogen from the Far East of Russia. Mycologia 101:841-852

558 https://doi.org/10.3852/08-217

559 Yli-Mattila T, Paavanen-Huhtala S, Parikka P, Hietaniemi V, Jestoi M, Gagkaeva T,

560 Sarlin T, Haikara A, Laaksonen S, Rizzo A., 2008. Real-time PCR detection and quantification

561 of Fusarium poae, $F$ graminearum, $F$ sporotrichioides and F langsethiae as compared to

562 mycotoxin production in grains in Finland and Russia. Archives of Phytopathology and Plant

563 Protection 41:243-260 https://doi.org/10.1080/03235400600680659 
Figure 1

The fungal perithecia and spores, and the symptoms of Fusarium disease of cereals from the Far East of Russia presented in the book by N. A. Palchevsky (1891).

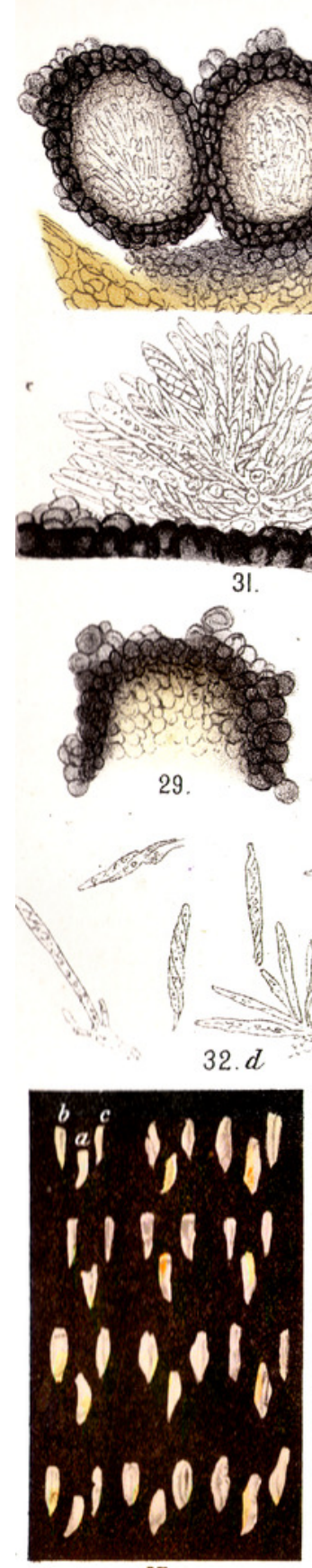

37.

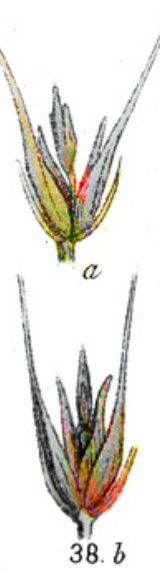

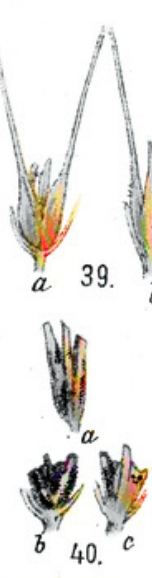

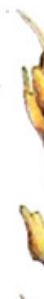

32. $a$
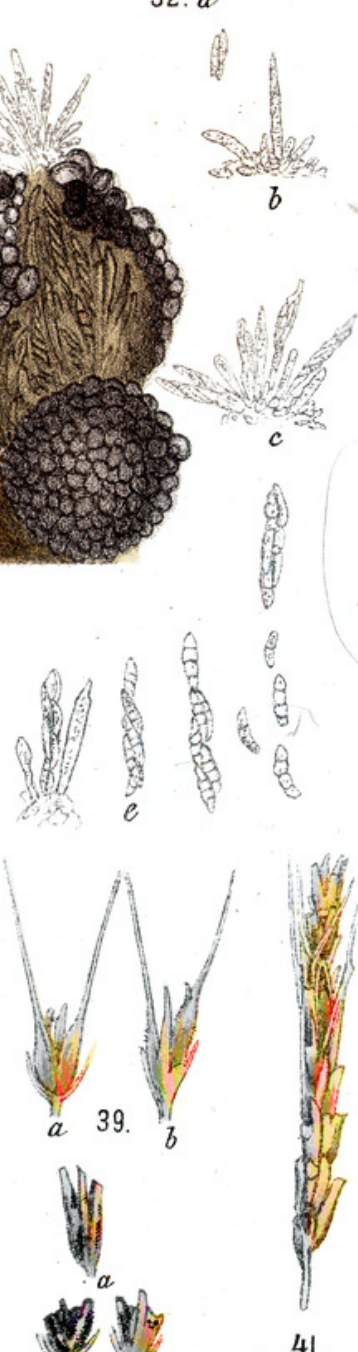

41.

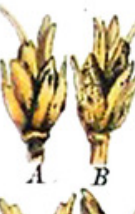

400

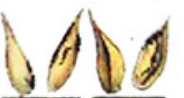

0000

A.

(1)

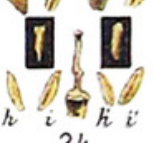

${ }_{h}{ }_{34}{ }_{h i}$
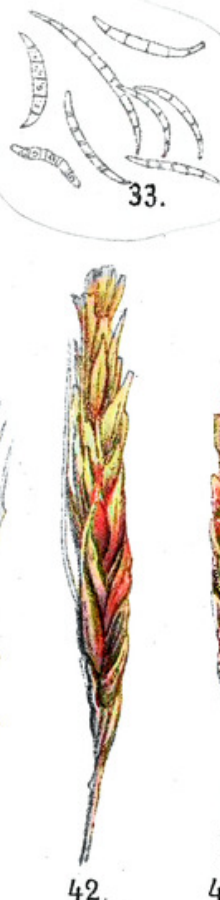

42.
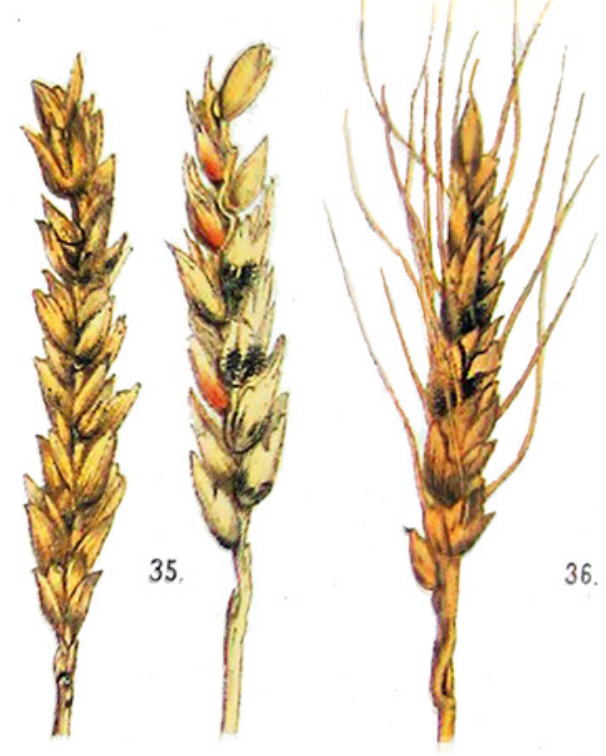

36.

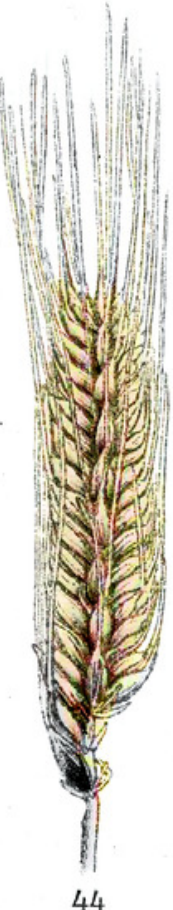

44.

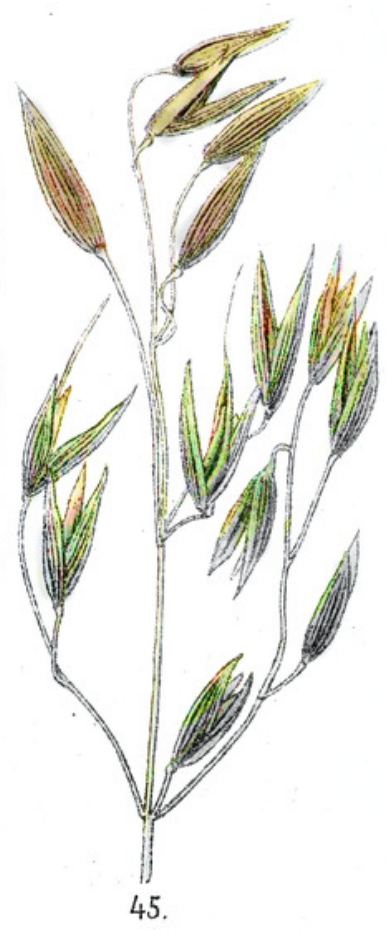


Figure 2

The diseased wheat (A) and barley grains (C); colony of $F$. graminearum on PSA, 10 days (B); macroconidia F. graminearum (D); the perithecia (E); expulsion of asci and ascospores from the perithecia (F). Scale bars: $D=20 \mu \mathrm{m} ; E=200 \mu \mathrm{m} ; F=5$ 


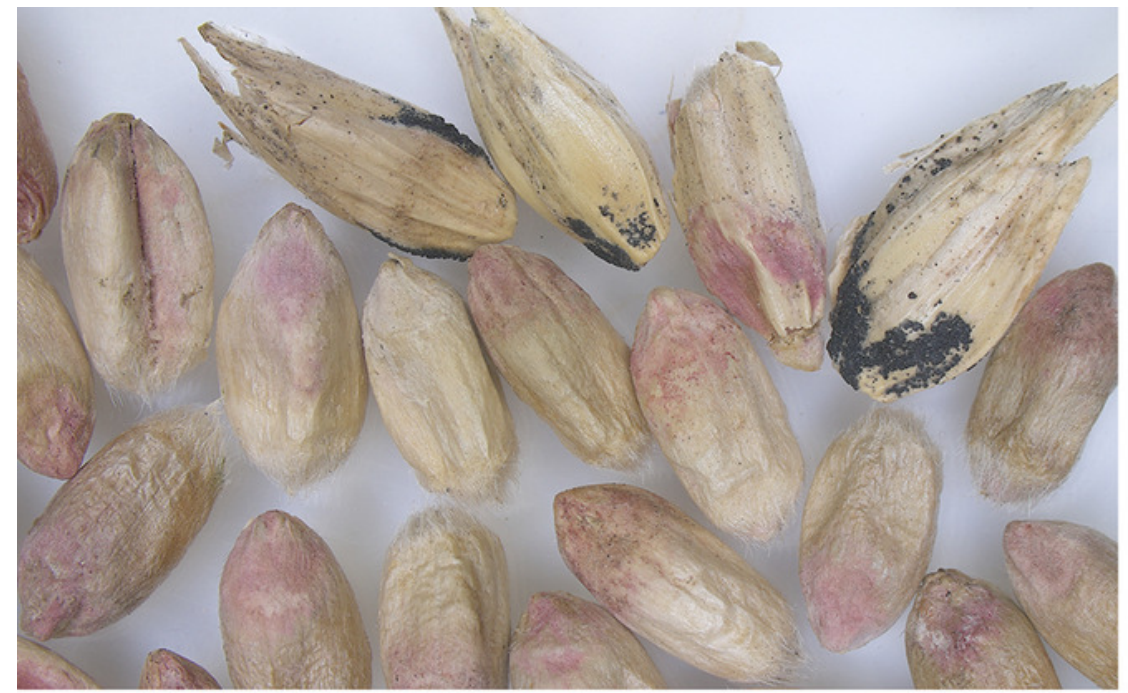

A
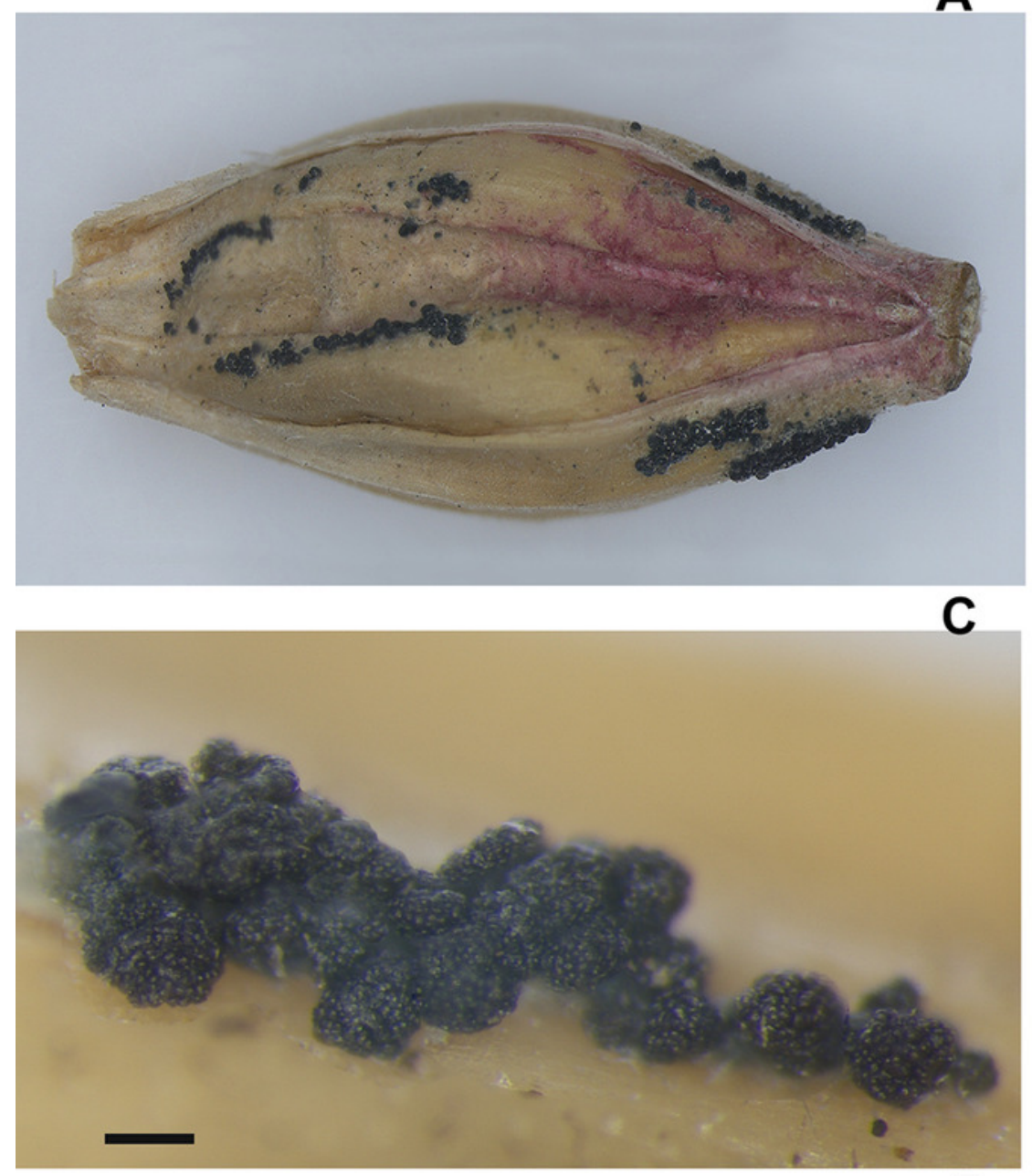

E

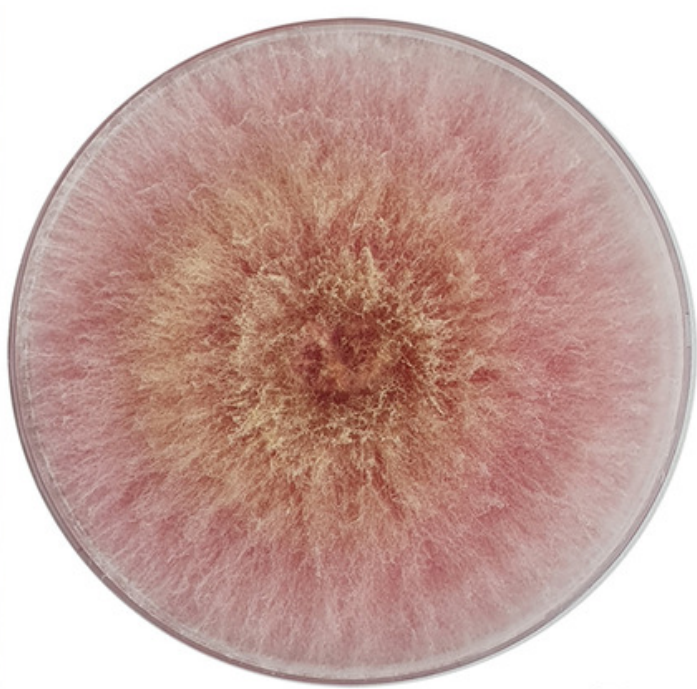

B

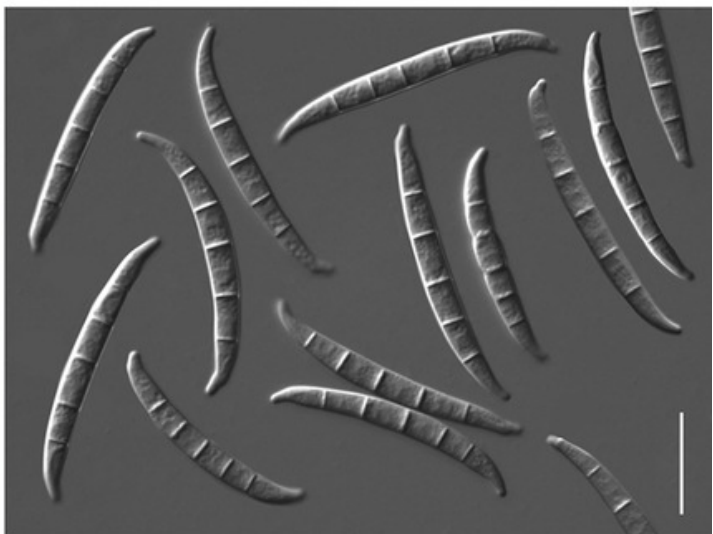

D

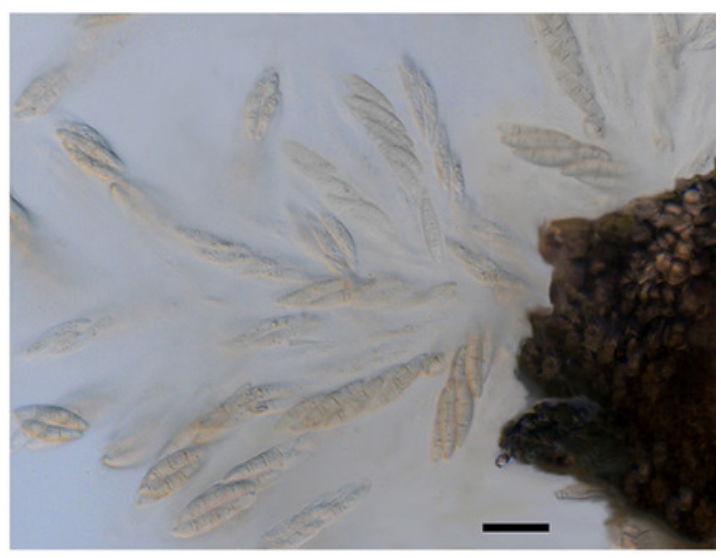

F 


\section{Figure 3}

Maximum likelihood (ML) phylogenetic tree based on DNA sequence data from fragments of the translation elongation factor EF-1a (TEF), ammonium ligase gene (URA), reductase gene (RED), and 3-0-acetyltransferase gene (Tri101) of [i]F

Numbers on the nodes are ML and maximum parsimony bootstrap support values greater than $70 \%$, followed by Bayesian posterior probability scores greater than 0.95 . Reference Fusarium isolates with NRRL number are indicated in bold. F. pseudograminearum was used as an outgroup. 


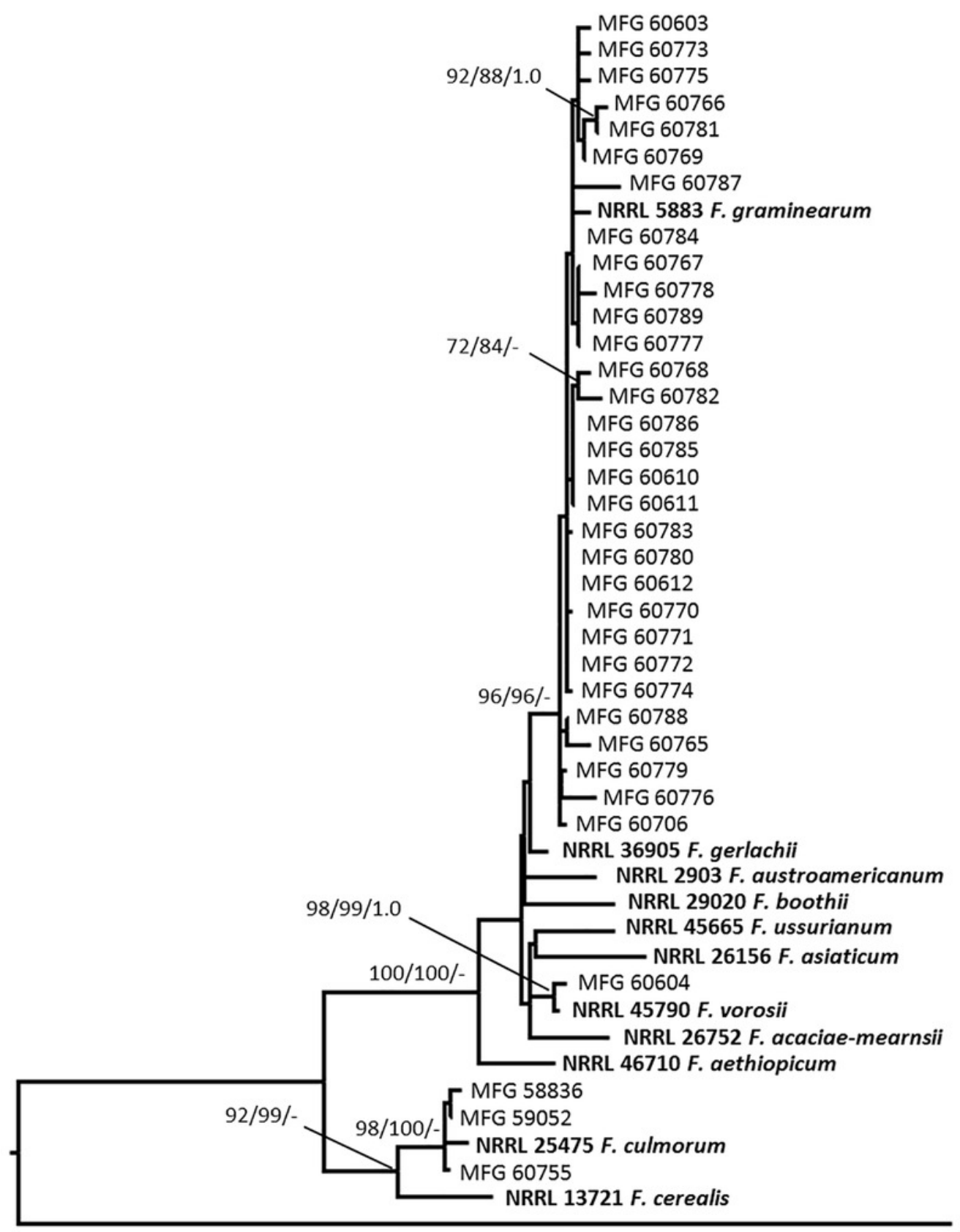

NRRL 28334 F. pseudograminearum 0.01 


\section{Table 1 (on next page)}

Climatic data during the growing season of 2019 in the Amur region (https://rp5.ru/) 


\begin{tabular}{lllllll}
\hline \multirow{2}{*}{ Month } & \multicolumn{3}{c}{ Average temperature, ${ }^{\circ} \mathrm{C}$} & Average & Total & Days with \\
\cline { 2 - 5 } & mean & min & $\max$ & humidity, $\%$ & rainfall, mm & precipitation \\
\hline May & +12.0 & -1.6 & +27.5 & 56 & 17 & 19 \\
June & +18.2 & +7.2 & +30.1 & 66 & 46 & 21 \\
July & +21.1 & +13.5 & +30.2 & 83 & 300 & 27 \\
August & +18.6 & +10.6 & +29.2 & 82 & 206 & 25 \\
\hline
\end{tabular}

1 


\section{Table 2 (on next page)}

Fusarium strains included in the study

${ }^{\text {a }}$ NRRL- the ARS Culture Collection (USA); nucleotide sequences of these reference strains were used in phylogenetic analysis. MFG - the fungal collection of Laboratory of Mycology and Phytopathology, All-Russian Institute of Plant Protection (Russia); the studied strains. ${ }^{b}$ The translation elongation factor EF-1a (TEF), ammonium ligase gene (URA), reductase gene (RED), and 3-0-acetyltransferase gene (Tri101). ${ }^{c}$ Bold indicates the number of sequence obtained in this study. 


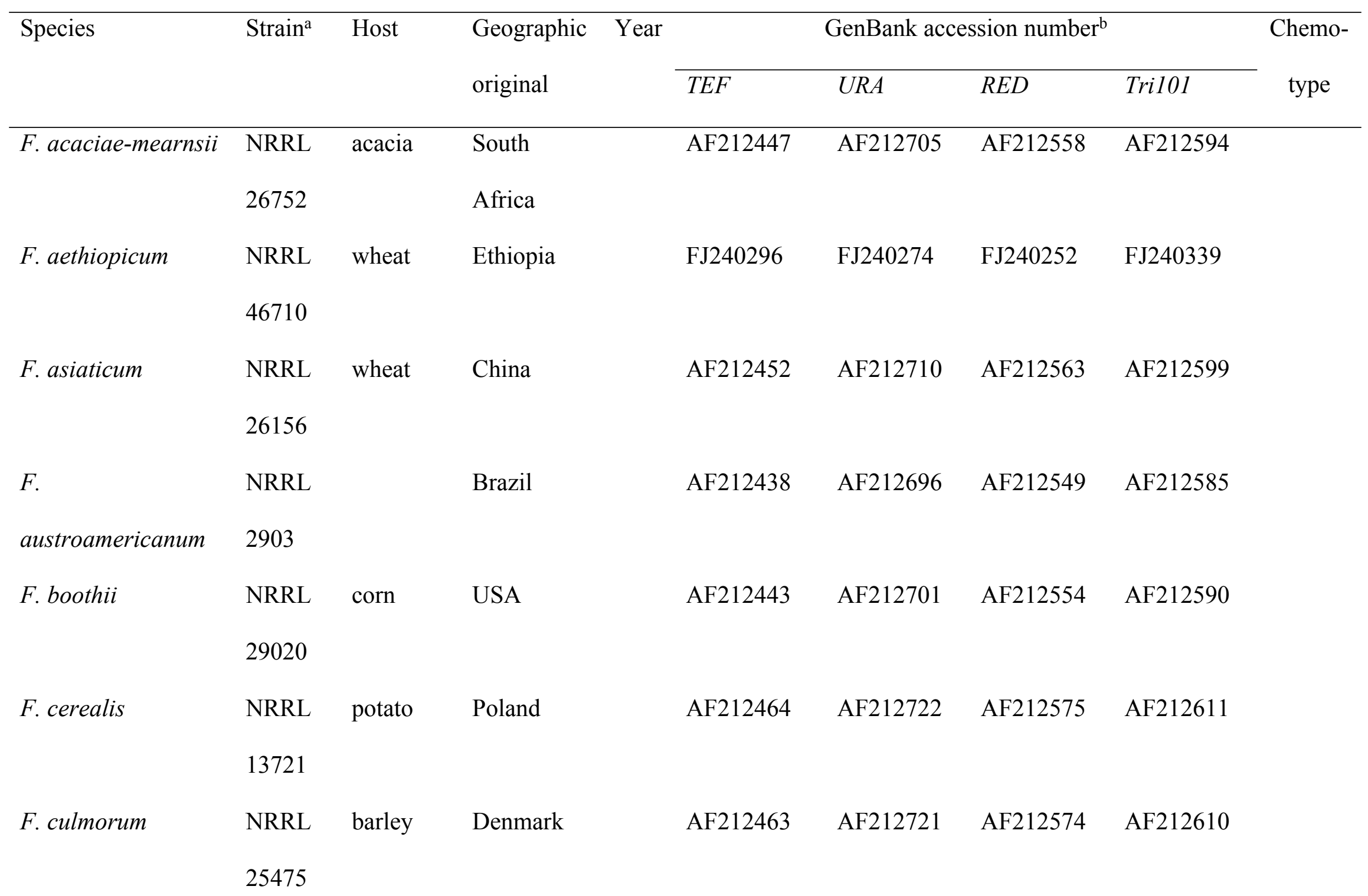




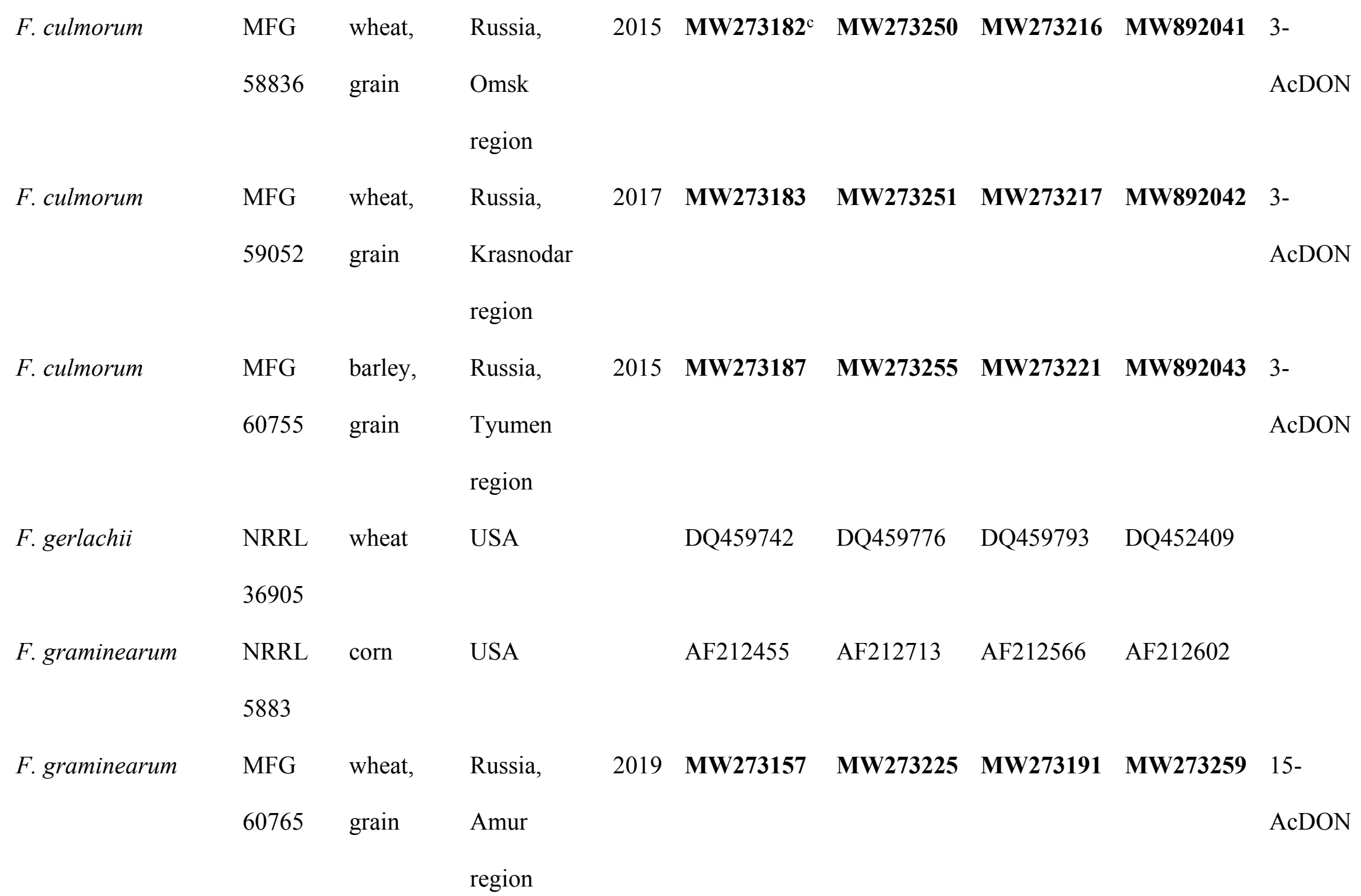




\begin{tabular}{|c|c|c|c|c|c|c|c|c|c|}
\hline \multirow[t]{2}{*}{ F. graminearum } & MFG & wheat, & Russia, & 2019 & MW273168 & MW273236 & MW273202 & MW273270 & $15-$ \\
\hline & 60766 & grain & Amur & & & & & & AcDON \\
\hline & & & region & & & & & & \\
\hline \multirow[t]{3}{*}{ F. graminearum } & MFG & wheat, & Russia, & 2019 & MW273176 & MW273244 & MW273210 & MW273278 & $15-$ \\
\hline & 60767 & grain & Amur & & & & & & AcDON \\
\hline & & & region & & & & & & \\
\hline \multirow[t]{3}{*}{ F. graminearum } & MFG & wheat, & Russia, & 2019 & MW273177 & MW273245 & MW273211 & MW273279 & $15-$ \\
\hline & 60768 & grain & Amur & & & & & & AcDON \\
\hline & & & region & & & & & & \\
\hline \multirow[t]{3}{*}{$F$. graminearum } & MFG & wheat, & Russia, & 2019 & MW273181 & MW273249 & MW273215 & MW273283 & $15-$ \\
\hline & 60769 & grain & Amur & & & & & & AcDON \\
\hline & & & region & & & & & & \\
\hline \multirow[t]{3}{*}{$F$. graminearum } & MFG & wheat, & Russia, & 2019 & MW273186 & MW273254 & MW273220 & MW273286 & $3-$ \\
\hline & 60770 & grain & Amur & & & & & & AcDON \\
\hline & & & region & & & & & & \\
\hline F. graminearum & MFG & wheat, & Russia, & 2019 & MW273188 & MW273256 & MW273222 & MW273287 & $15-$ \\
\hline
\end{tabular}




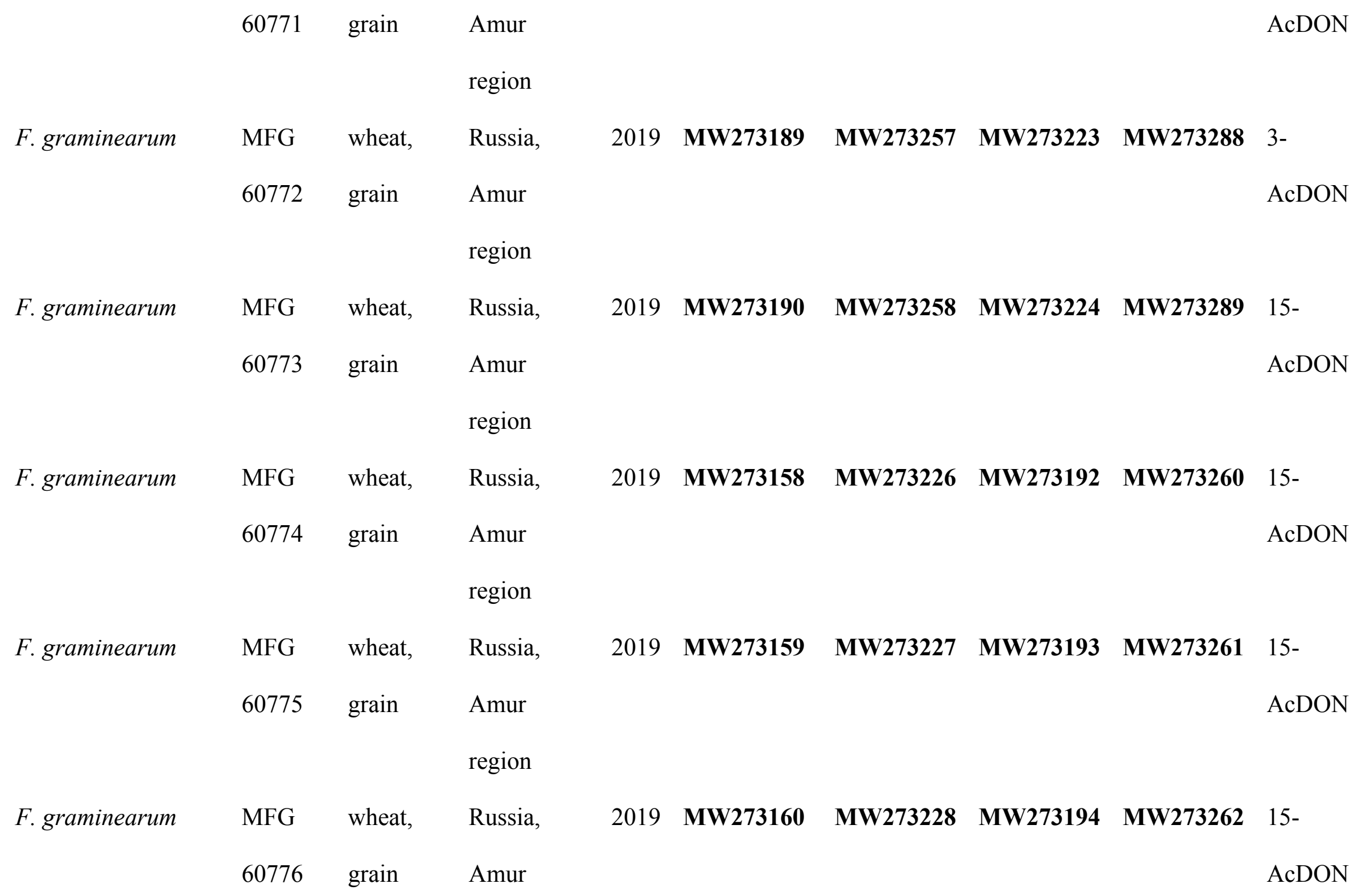




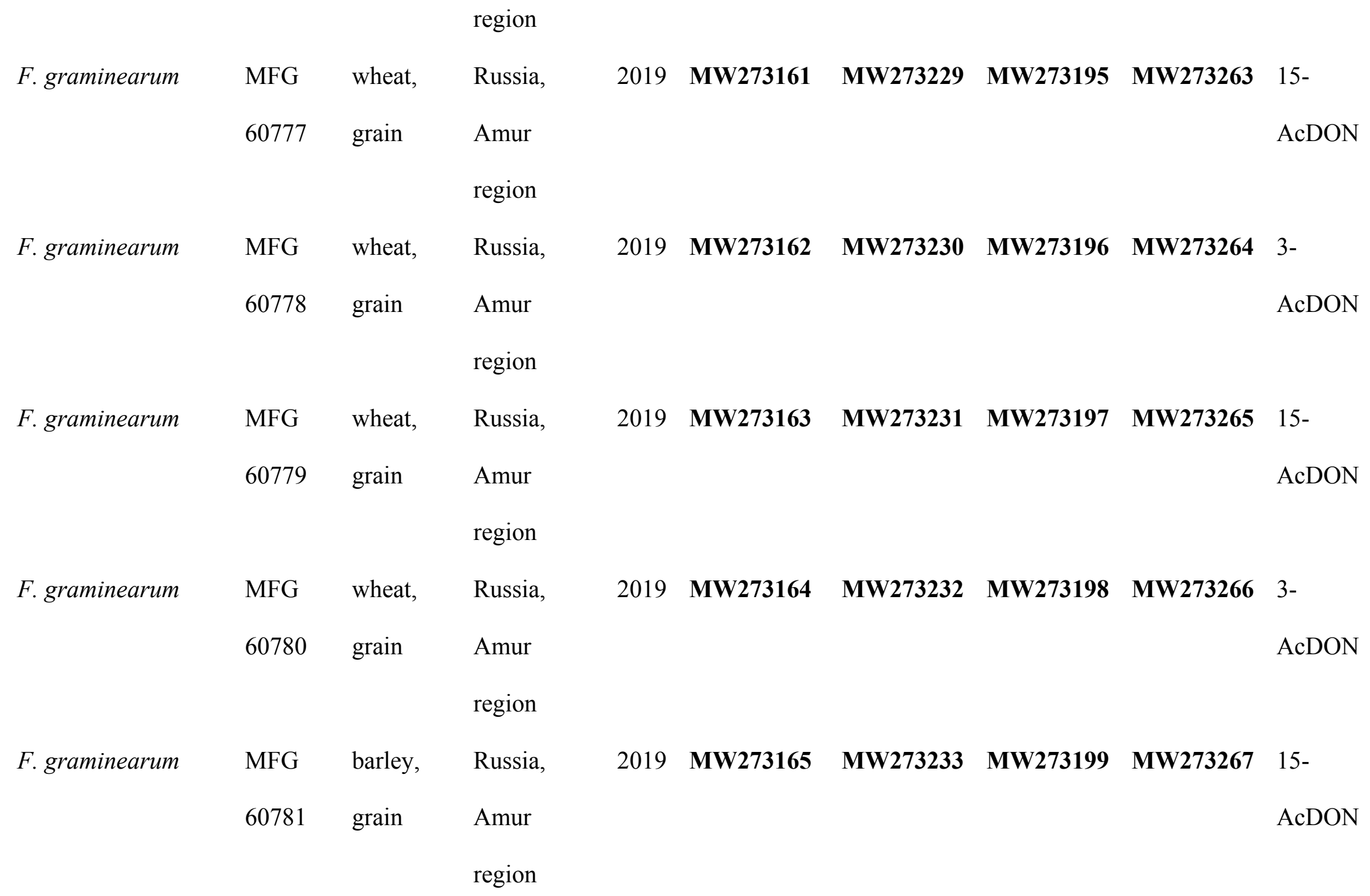




\begin{tabular}{|c|c|c|c|c|c|c|c|c|c|}
\hline$F$. graminearum & MFG & barley, & Russia, & 2019 & MW273166 & MW273234 & MW273200 & MW273268 & $3-$ \\
\hline & 60782 & grain & $\begin{array}{l}\text { Amur } \\
\text { region }\end{array}$ & & & & & & AcDON \\
\hline F. graminearum & $\begin{array}{l}\text { MFG } \\
60783\end{array}$ & $\begin{array}{l}\text { barley, } \\
\text { grain }\end{array}$ & $\begin{array}{l}\text { Russia, } \\
\text { Amur } \\
\text { region }\end{array}$ & 2019 & MW273167 & MW273235 & MW273201 & MW273269 & $\begin{array}{l}\text { 3- } \\
\text { AcDON }\end{array}$ \\
\hline F. graminearum & $\begin{array}{l}\text { MFG } \\
60784\end{array}$ & $\begin{array}{l}\text { barley, } \\
\text { grain }\end{array}$ & $\begin{array}{l}\text { Russia, } \\
\text { Amur } \\
\text { region }\end{array}$ & 2019 & MW273169 & MW273237 & MW273203 & MW273271 & $\begin{array}{l}\text { 3- } \\
\text { AcDON }\end{array}$ \\
\hline F. graminearum & $\begin{array}{l}\text { MFG } \\
60785\end{array}$ & $\begin{array}{l}\text { barley, } \\
\text { grain }\end{array}$ & $\begin{array}{l}\text { Russia, } \\
\text { Amur } \\
\text { region }\end{array}$ & 2019 & MW273170 & MW273238 & MW273204 & MW273272 & $\begin{array}{l}\text { 3- } \\
\text { AcDON }\end{array}$ \\
\hline$F$. graminearum & $\begin{array}{l}\text { MFG } \\
60786\end{array}$ & $\begin{array}{l}\text { barley, } \\
\text { grain }\end{array}$ & $\begin{array}{l}\text { Russia, } \\
\text { Amur } \\
\text { region }\end{array}$ & 2019 & MW273171 & MW273239 & MW273205 & MW273273 & $\begin{array}{l}15- \\
\text { AcDON }\end{array}$ \\
\hline$F$. graminearum & MFG & barley, & Russia, & 2019 & MW273172 & MW273240 & MW273206 & MW273274 & $15-$ \\
\hline
\end{tabular}




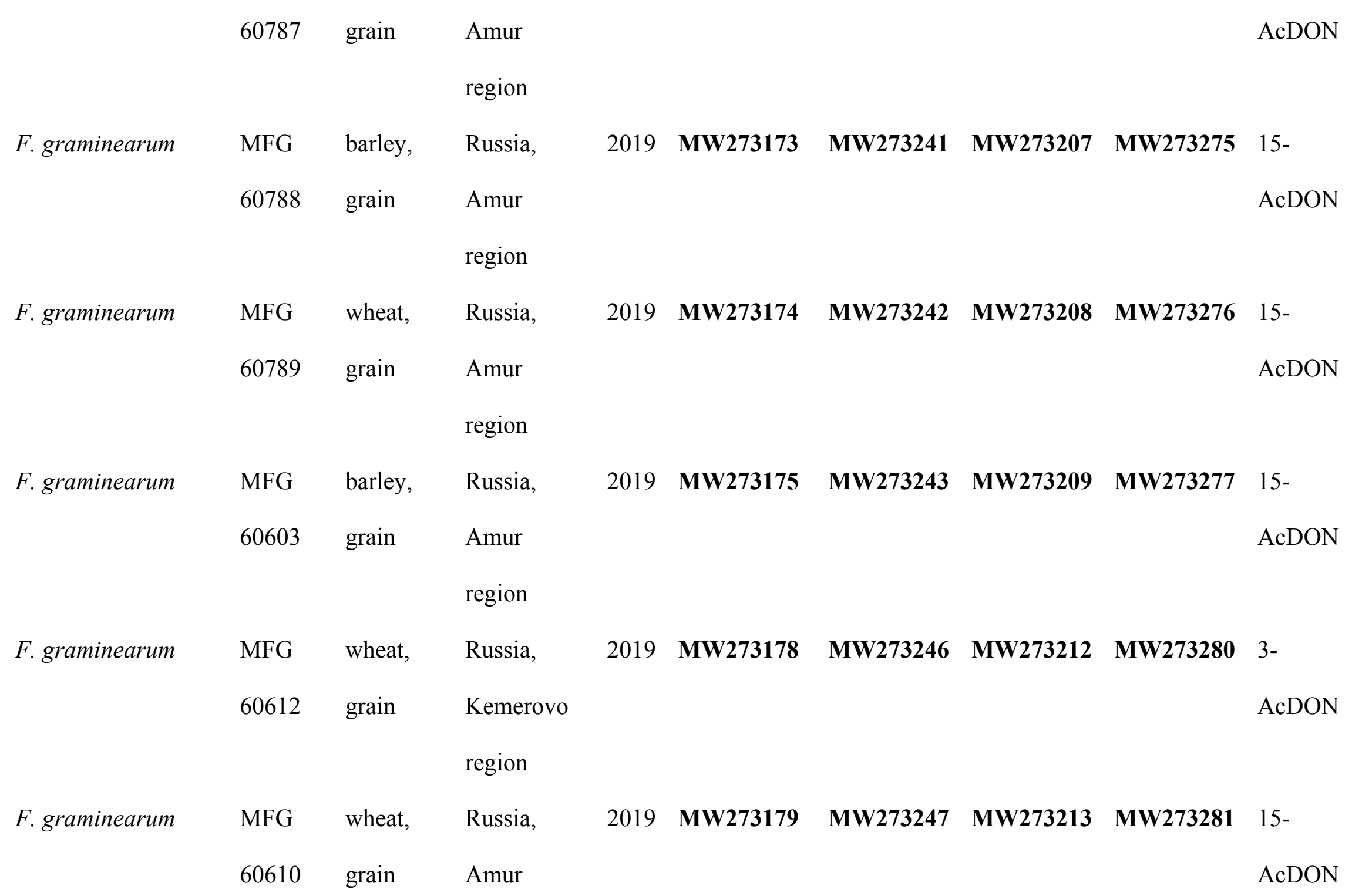




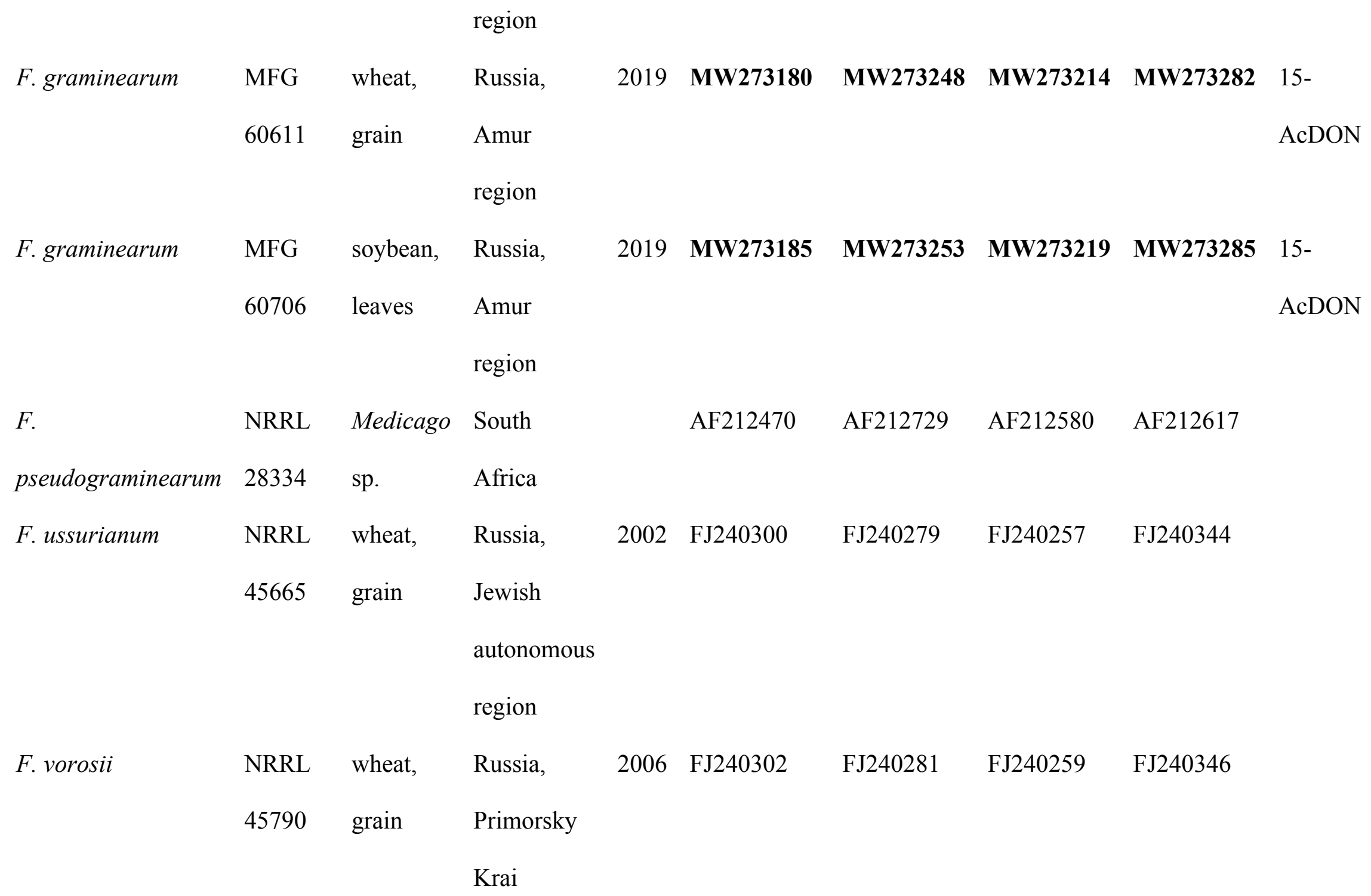


F. vorosii MFG wheat,

Russia,

2018 MW273184

MW273252

MW273218 MW273284

$15-$

60604 grain Altay Krai AcDON

1 
Table 3(on next page)

Infection of wheat and barley grain grown in the Amur region in the Russian Far East, 2019 


\begin{tabular}{|c|c|c|c|}
\hline \multirow[t]{2}{*}{ Parameters } & & \multicolumn{2}{|l|}{ Samples of grain } \\
\hline & & Wheat & Barley \\
\hline Grain infected with fungi & Fusarium spp. & $81.1(58-98)$ & $80.5(64-94)$ \\
\hline on average (range), $\%$ & incl. $F$. graminearum & $68.0(47-88)$ & $72.0(61-92)$ \\
\hline Content of mycotoxins & DON & $7,498(3,207-13,343)$ & $\mathbf{5 , 3 9 0}(912-7,756)$ \\
\hline \multirow[t]{5}{*}{ on average (range), ppb } & 3-AcDON & $122(27-293)$ & $131(0-192)$ \\
\hline & 15-AcDON & $85.5(23-179)$ & $93.5(19-154)$ \\
\hline & 3-DON-glucoside & $\mathbf{1 , 0 1 1}(299-2,001)$ & $\mathbf{2 , 1 2 8}(98-3,803)$ \\
\hline & $\mathrm{ZEN}$ & $\mathbf{1 , 1 5 3}(92-3,670)$ & $537(111-928)$ \\
\hline & MON & $70.2(10-218)$ & $72.7(5-207)$ \\
\hline Amount of Fusarium & F. graminearum & $\mathbf{6 , 0 8 9}(2,658-11,342)$ & $\mathbf{2 , 1 0 2}(163-3,557)$ \\
\hline DNA $\times 10^{-3}$ on average & 3-AcDON genotype & $\mathbf{1 , 0 8 4}(395-2,007)$ & $508(107-783)$ \\
\hline \multirow[t]{2}{*}{ (range), $\mathrm{pg} / \mathrm{ng}$} & 15-AcDON genotype & $1,708(755-2,776)$ & $371(101-713)$ \\
\hline & F. avenaceum & $40(6-97)$ & $13(3-38)$ \\
\hline
\end{tabular}

